\title{
OFFSHORE WIND ENERGY RESOURCE ASSESSMENT IN MALAYSIA WITH SATELLITE ALTIMETRY
}

\author{
FARAH ELLYZA HASHIM*1, OSCAR PEYRE ${ }^{2}$, SARAH JOHNSON LAPOK ${ }^{1}$, OMAR \\ YAAKOB $^{1,3}$ AND AMI HASSAN MD DIN ${ }^{4}$
}

'School of Mechanical Engineering, Faculty of Engineering, Universiti Teknologi Malaysia, 81310 UTM Johor Bharu, Johor, Malaysia. 'Graduate School of Engineering, Ecole Polytechnique France (EPF), 3, Bis Rue Lakanal, 92330 Sceaux, France. ${ }^{3}$ Marine Technology Center (MTC), Universiti Teknologi Malaysia, 81310 UTM Johor Bharu, Johor, Malaysia. Geomatic Innovation Research Group (GnG), Faculty of Built Environment and Surveying, Universiti Teknologi Malaysia, 81310 UTM Johor Bharu, Johor, Malaysia.

*Corresponding author: farahellyza@utm.my

Submitted final draft: Accepted:

http://doi.org/10.46754/jssm.2020.08.010

\begin{abstract}
Realistic view on the potential of offshore wind farm development in Malaysia is necessary and requires accurate and wide coverage of wind speed data. Long term global datasets of satellite altimetry of wind speed provide a potentially valuable resource to identify the potential of offshore wind energy in Malaysia. This paper presents three different assessments of offshore wind energy resources in Malaysia using satellite altimetry. The wind speed data obtained from Radar Altimeter Database System (RADS) were validated and identified to be in agreement with previous studies. The resources were then assessed at three different levels; theoretical, technical and practical offshore wind energy potential. The technical resource potential was assessed by taking into consideration the available offshore wind turbine technology. Conflicting uses and environmental constraints that define the practical offshore wind energy resources are plotted on the maps to present a practicality of offshore wind farm development in Malaysian sea. The study concluded that, in theoretical view, Malaysia does have potential of offshore wind energy resource especially in Borneo Water with average annual wind energy density above $500 \mathrm{kWh} / \mathrm{m}^{2}$. However, the development of offshore wind farm in Malaysia will be difficult taking into consideration the technical and practical challenge.
\end{abstract}

Keywords: Satellite altimetry, RADS, offshore wind energy, assessment, wind turbine, Malaysia .

\section{Introduction}

High oil prices together with a growing concern over the environmental impact of fossil fuels has stirred the search for substitutes. Malaysia is essentially blessed with good generation mix of energy resources varying from conventional sources such as oil, natural gas and coal to renewable energy resources from the likes of solar installations, hydropower plants and biomass. Figure 1 presents the increasing demand of energy supply from various resources in Malaysia from 1997 to 2017 as reported by the Energy Commission of Malaysia (Energy Commission, 2017). Coal usage has increased from 5\% in 1997 to $20 \%$ in 2017 and has been exchanged from natural gas as the main source of energy.
Due to this current scenario, the Malaysia government is driven to have a deliverance to electricity supply with energy efficiency and renewable energy for the people. The then Minister of Energy, Science, Technology, Environment and Climate Change, Yeo Bee Yin during the Conference of the Electric Power Supply Industry at the Kuala Lumpur Convention Center in 2018, stated Malaysia was expecting 20 per cent of the country's energy to be generated from renewable sources by 2025 . The initiatives the initiative was to increase the renewable energy mix in electric supply that reduces the consumption of fossil fuels and greenhouse gas emissions (Landau, 2019). It has been embedded in the Wawasan Kemakmuran Bersama 2030 (WKB2030) under the Key 
Economic Growth Activities (KEGA11). This is in continuation to several acts and plans, for example Renewable Energy Act 2011 and National Renewable Energy Policy that have been introduced by the government to further boost the development of renewable energy in Malaysia (Ghazali \& Ansari, 2018).

The National Renewable Energy Policy vision is to achieve 20\% Renewable Energy (RE) capacity mix by 2025 . Wind energy is easily accessible and has minor environmental impacts and as such it is considered as one of the green energy sources. Malaysia experiences two monsoon wind seasons, the Northeast and Southwest monsoon seasons, with the Northeast Monsoon bringing heavier rainfall with wind speed that could reach up to $15 \mathrm{~m} / \mathrm{s}$ particularly in the east coast of Peninsular Malaysia. The typhoons striking neighboring countries may also affect on strong winds exceeding $10 \mathrm{~m} / \mathrm{s}$ blowing to Sabah and Sarawak (Albani et al., 2014) (Syakirah et al. 2019) region may provide a potential for wind energy sources, specifically offshore wind energy.

Unlike onshore wind energy, there is a lack of studies that correlate with offshore wind energy potential, especially at Malaysia. However, the potential of this renewable energy needs to be explored as the International Energy Agency (IEA) suggested that offshore wind farms have the potential to generate up to $50 \%$ more electricity than an onshore wind farm as the wind speed is steadier and higher (IEA, 2006) Also, offshore wind farm is usually built further from the coast that reduces the environmental issues particularly with regard to noise, visual constraints and space limitations. In addition, offshore wind turbine generators (WTGs) typically have larger diameter blades due the accesibility of larger sites for construction, resulting yield higher rated power.

Based on the monthly summary of marine meteorological observations published by the Malaysian Meteorological Service (MMS), Chiang et al. (2003) analysed the potential of offshore wind energy resource at 16 locations in Malaysia. It is estimated that the annual offshore wind speed for Malaysian waters is approximately 1.2 to $4.1 \mathrm{~m} / \mathrm{s}$, with higher values being 3.3 to $4.1 \mathrm{~m} / \mathrm{s}$ in eastern Peninsular Malaysia. The study also suggested that the research was largely based on Visual Observation Ships (VOS) which were shown to have errors during observation data taking and reporting (Gulev et al., 2002).

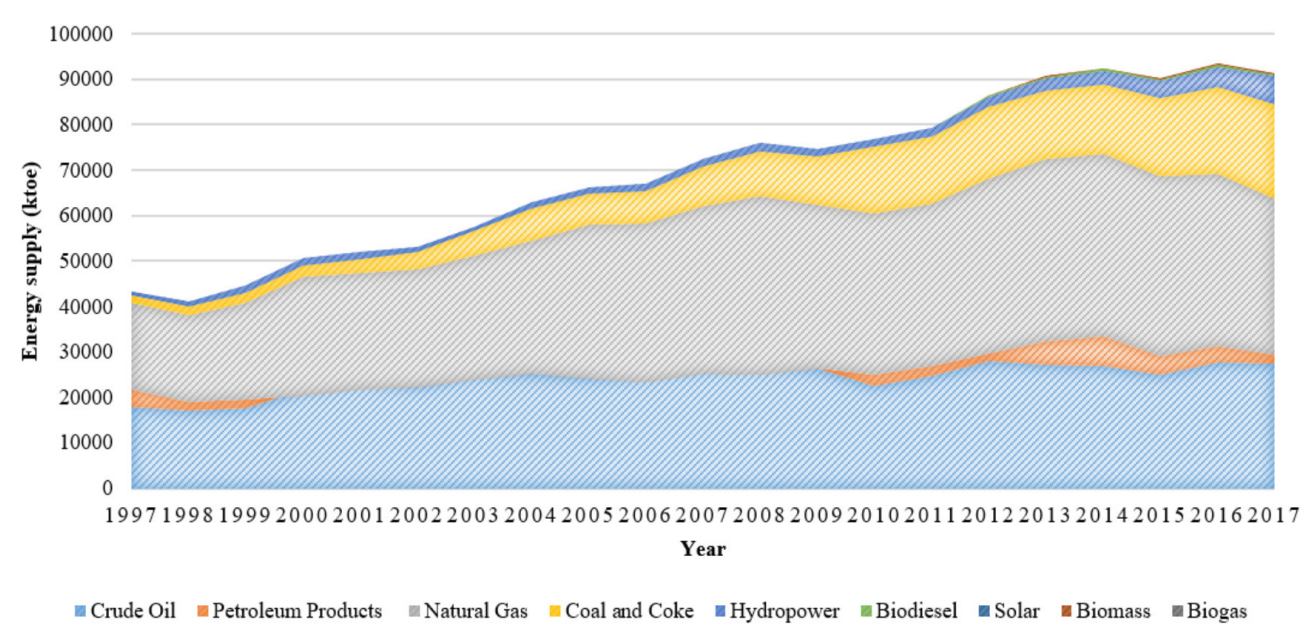

Figure 1: Increasing demand of energy supply in Malaysia over 20 years (1997 - 2017) (Energy Commission, 2017) 
For 6 selected sites in Malaysia, an additional preliminary feasibility study of offshore wind power was conducted using HOMER software (Mekhilef \& Chandrasegaran, 2011). The study appraised some technical aspects in the energy analysis including offshore wind flow prediction, wind farm design, wind farm electrical transmission losses coefficient and wind farm availability. The study found that Site 2, located off the Terengganu coast facing the South China Sea, is the best choice for offshore wind farm implementations having high wind resource availability of $4.1 \mathrm{~m} / \mathrm{s}$ with the maximum potential during Northeast monsoon season. The economic feasibility of two models of the wind turbines with different rated power were also considered, with the 0.66 MW rated wind turbine providing higher net specific production compared to the $2 \mathrm{MW}$ rated wind turbine.

On the other hand, according to the availability of QuickSCAT satellite wind data, Albani et al. (2014) assessed the potential of offshore wind power for electricity generation in Kijal, Malaysia.Their results indicate that the high wind speeds are between 4.0 to 8.0 $\mathrm{m} / \mathrm{s}$. For energy and economic analysis, seven types of wind turbines with different rated power are considered. The study also pointed out that attention must be given to the areas of environmental exclusion or shipping lanes or traffic zones during site selection to locate the wind turbine. However, no exclusion areas were assumed on the selected site. Ahmad Zaman et al. (2019) performed another analysis of offshore wind energy resources in Malaysia using satellite altimetry. This study identified three potential areas for offshore wind energy development in Peninsular Malaysia and Borneo with an estimation of over $500 \mathrm{kWh} / \mathrm{m}^{2}$ of annual wind energy.

Generally, previous researchers assessed theoretical and technical potential of offshore wind energy using various wind data resources. However, there is a need to differentiate and analyse the theoretical, technical and practical potential with accurate and reliable wind data.
In this paper, three separate assessments were performed using satellite altimetry to show a realistic view of the potential of offshore wind power in Malaysia. The theoretical potential centers around the annual energy yield, while the technological potential of offshore wind turbine engineering is taken into account. On the other hand, the practical potential focuses on the physical, socioeconomic and environmental constraints for the development of offshore wind farm in Malaysia.

\section{Wind Data Sets}

There are various types of available data sources for wind speed and direction, which include the model prediction of wind speed, visual observation, instrumental measurements and also remote sensing. Buoy measurement is the most dependable wind data source as mechanical instruments are used to measure it directly. Yet, the number of buoy deployments in the ocean is limited especially in Malaysian waters (Witter \& Chelton, 1991). This impedes the effort for an accurate and reliable analysis on offshore wind energy resources particularly for Malaysia. Other than that, the application of satellite altimetry to evaluate the wind energy resource has attracted significant attention. Therefore, this gives an alternative option into providing precise and stable data worthy of temporal and spatial coverage.

Satellite altimeter in general measures the distance from the satellite towards a target surface by measuring the satellite-to-surface round trip time of a radar pulse. Figure 2 illustrates the simple working principles of satellite altimeter. Returned signal gives several parameters such as slant of the reflected signal, distance from the sea level measured by the time travel of the pulses and the determination of wind speed by the power from the impulse response. Satellite altimeter is also able to provide relatively accurate and reliable significant wave height which is an important parameter for determination of wave energy resource assessment (Wan et al., 2015; Ye et al., 2015; Yaakob et al., 2016). 
Various studies have been conducted to analyse the measurement validity of wind speed from satellite altimeter. The current study has previously validated the satellite derived wind speed measured at $10 \mathrm{~m}$ above surface with the buoy measurement at similar height in Sarawak using collocated method (readers are suggested to refer to Ahmad Zaman et al. (2019)). It is concluded that the correlation of both measurements is 0.835 with a bias of $0.549 \mathrm{~m} / \mathrm{s}$ and a Root Mean Square Error (RMSE) of 1.385 $\mathrm{m} / \mathrm{s}$. These findings are in line with several other studies which present the reliability of satellite altimetry to support wind energy analysis (Uti et al., 2013; Hasager et al., 2015; Guo et al., 2018).

Within this study, multiple mission satellite altimeters that include TOPEX/Poseidon, Jason-1, OSTM/Jason-2, ERS-1, ERS-2, and Envisat are used to obtain the wind speed dataset. The data obtained was from the Radar Altimeter Database System (RADS) that is situated at the Global Navigation Satellite System (GNSS) and Geodynamics Laboratory, Universiti Teknologi Malaysia. RADS is a software developed with integrated, approved and calibrated sea-level directory from the multi-mission altimeter and enables users to access, process and validate their own altimetry data with accurate database and precise parameters. For the purpose of this study, wind speed data over at a period of 10 years, from 2001 to 2010, were extracted from RADS for wind speed climatology assessment.

\section{Offshore Wind Energy Resource}

At present, assessment conducted by various researchers, particularly in the vicinity of Malaysia, were focusing on the theoretical or gross offshore wind resource and a part of technical resource potential. Figure 3 describes a more comprehensive classification framework developed by the National Renewable Energy Laboratory (NREL) for offshore wind energy resource assessment for the United States (US) (Musial et al., 2016).

By referring to the framework, the assessment in this study was divided into three categories; theoretical, technical and practical offshore wind energy resource.

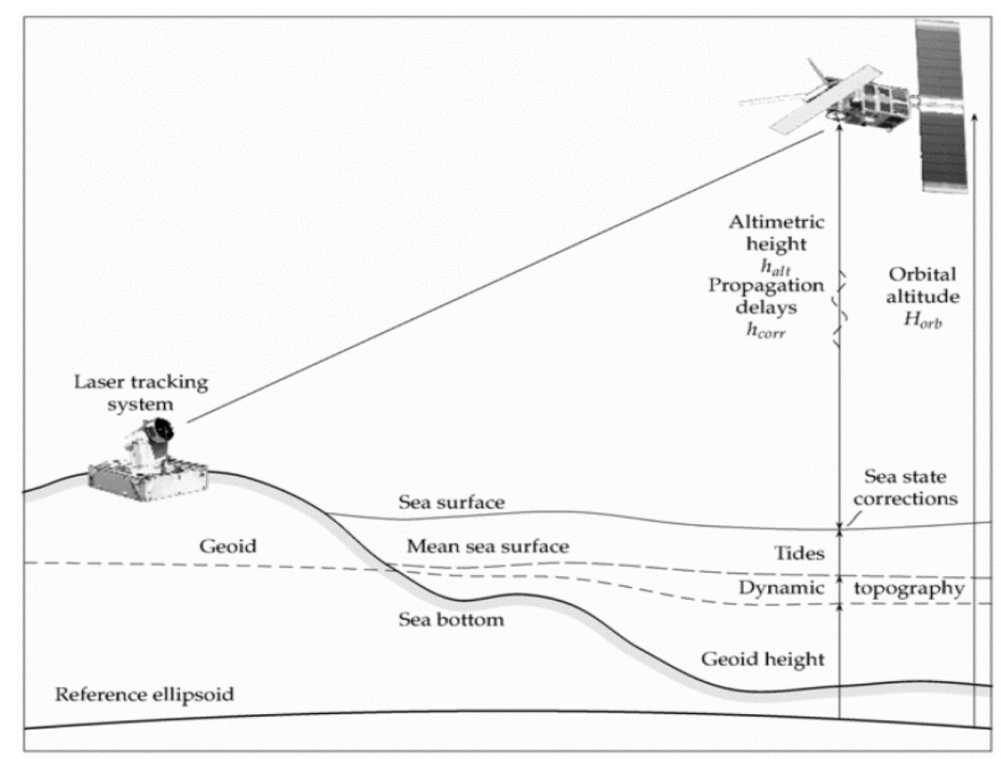

Figure 2: Working principle of satellite radar altimeter 


\section{Theoretical Offshore Wind Resource}

The Wind Power Density (WPD) can be obtained from $\boldsymbol{P}$ per unit of swept area, in $\mathrm{W} \mathrm{m}^{-2}$, where $\boldsymbol{P}$ is calculated usingEquation 1 (Rusu, 2019);

$$
P=\frac{1}{2} \rho_{a} v^{3}
$$

whereby $\boldsymbol{P}$ is power in watts, $\boldsymbol{P}_{\boldsymbol{a}}$ is known as air density (approximately $1.225 \mathrm{~kg} / \mathrm{m}^{3}$ at sea level that reduces with altitude), is the wind speed $(\mathrm{m} / \mathrm{s})$. The wind speed data from satellite altimetry is used in this calculation. Using the wind speed value obtained, the wind energy density at the particular area is calculated by multiplying with the total hours per year to generate a wind energy mapping which gives an insight into the energy capacity that is stored at Malaysia waters.

The theoretical wind resource is represented by calculating (WPD) using Equation 1 and mapped considering all areas from the shoreline of Malaysia without taking into account the possible technology, user conflicts or environmental impacts. This resource provides an insight into the maximum offshore wind potential but cannot be used as a reference for actual power production estimates. The WPD indicates energy available and is used to pre- determine the potential locations for deployment of wind turbine generators (WTGs).

\section{Technical Offshore Wind Resource}

The technical wind energy potential captures the subset of theoretical potential that can be considered using available offshore wind turbines suitable for the wind speed conditions in the particular area. Several technical parameters must be considered to make a preliminary assessment of the suitability of the turbines:

i. The rated power is the maximum power output of the turbine. It is proportional to the size of the turbine. It can go from about 20 Watts for very small turbines, to more than $8 \mathrm{MW}$ for the largest offshore wind plant installations.

ii. The diameter of the rotor usually depends on the rated power. The larger the rotor, the more energy the turbine would be able to harvest, but the number of turbines that can be installed is smaller.

iii. The cut in wind speed is the minimum speed of wind the turbine required to generate power. This parameter is very important as the wind turbine must operate reliably in areas with mean wind speed between 4

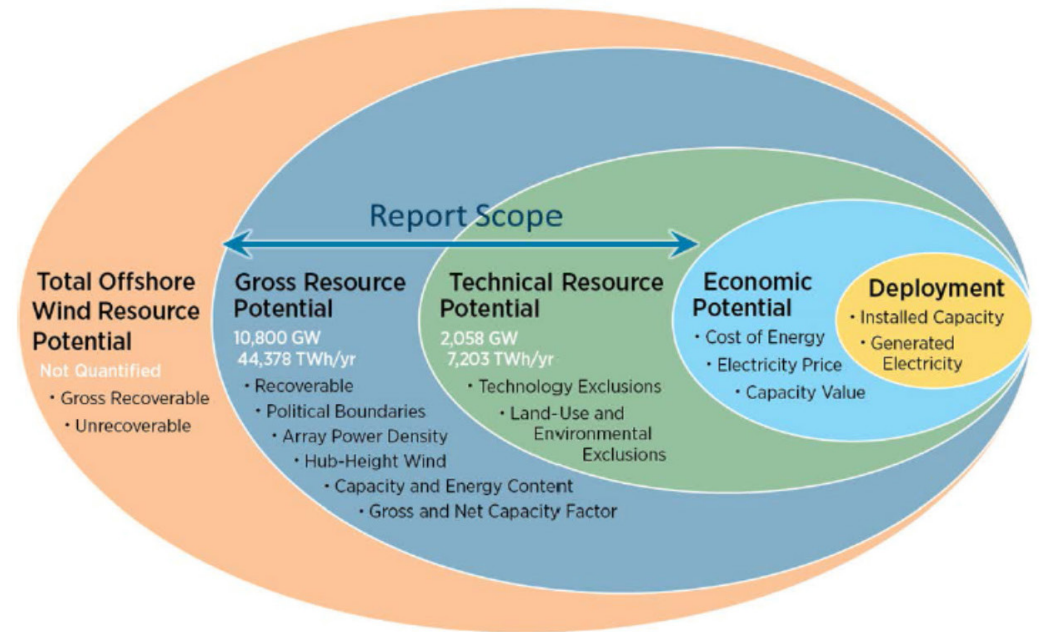

Figure 3: Offshore wind energy resource classification framework (Musial et al., 2016) 
and $6 \mathrm{~m} / \mathrm{s}$ like along the Malaysian coastal areas.

iv. The power curve of each turbine would enable it to estimate the annual energy production (AEP) for a given annual mean wind speed. Figure 4 shows a sample of power curve of ATB $60.28 \mathrm{DD}$ offshore wind turbine manufactured by ATB Riva Calzoni (ATB Riva Calzoni, n.d.). A cut in wind speed of this turbine is $3 \mathrm{~m} / \mathrm{s}$ and $9 \mathrm{~m} / \mathrm{s}$ of steady wind speed is required to produce
$60 \mathrm{~kW}$ rated output power. At annual mean wind speed of $5 \mathrm{~m} / \mathrm{s}$ in Malaysia for example, it is expected to generate AEP around $209 \mathrm{MWh} / \mathrm{y}$.

v. The capacity factor (CF) of a wind turbine is given at a certain wind speed which describes the capacity of the turbine to harvest the wind energy compared to its rated power. A good capacity factor lies between 20 and $30 \%$. Equation 2 is used to obtain the CF (\%):

$$
C F(\%)=\frac{A E P(k W h / \text { year })}{\text { Rated Power }(k W) \times 8760(h / \text { year })} \times 100
$$

The present study adopted the method proposed by Gadad and Deka (2016) by making use of altimetry averaged daily winds rather than averaged hourly wind speed. The altimetry data was averaged over the 10 - year period (2001 to 2010) to get the annual power in $\mathrm{kW}$. The The CF was calculated by Equation 3 as follows (Gadad \& Deka, 2016):

$$
C F=\text { Annual Power }(k W) / \text { Rated Power }(k W)
$$

\section{Practical Offshore Wind Resource}

Along with the technical potential assessment, it is crucial to include the spatial, socioeconomic and environmental constraints to develop offshore wind farm in potential locations to harness the offshore wind energy. Nie and Li (2018), for example, considered several spatial constraints such as shipping lanes, bird flight path, cables and pipelines and visibility to calculate the geographic area available for developing offshore wind energy observed that for nearshore region considered in their study, only $48.1 \%$ of the area available and free of spatial constraints.

The Scottish Government (Marine Scotland Science, 2018) outlined several criteria, mainly wind resources, water depth, ports and power grids, based on an empirical analysis conducted

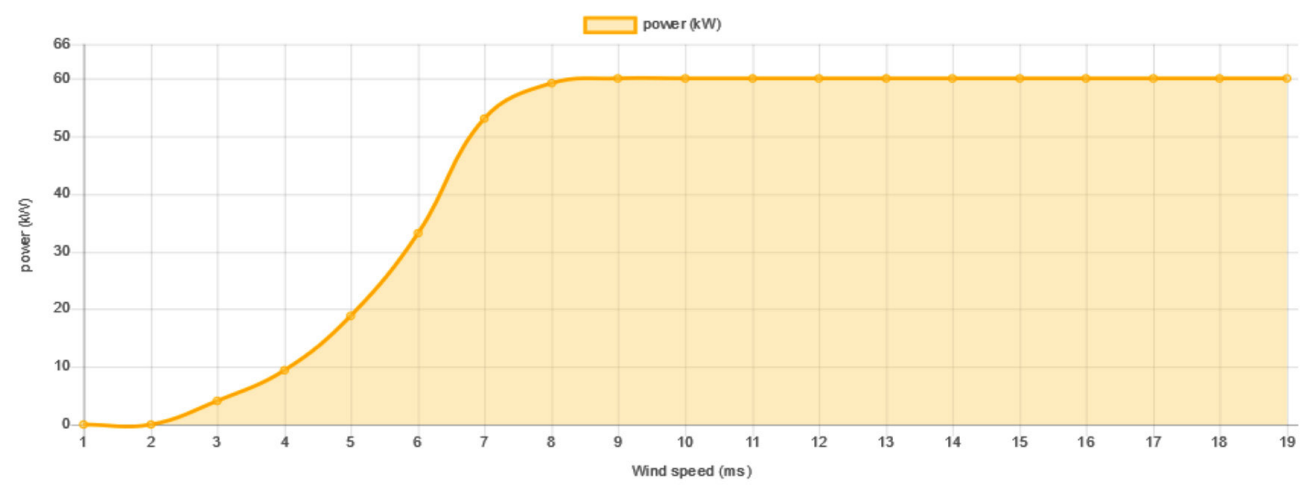

Figure 4: Power curve of ATB Riva Calzoni ATB 60.28DD (ATB Riva Calzoni, n.d.) 
on an offshore wind farm that was to be built in Scottish waters. As for wind resources, speeds of at least $8 \mathrm{~m} / \mathrm{s}$ in locations a minimum of 10 to $20 \mathrm{~km}$ away from the coast were required while water depth must be as deep as 40 to $50 \mathrm{~m}$. Meanwhile, ports are suggested as ideal places for power generation facilities because of their resources and manpower and the location of power grids was considered as they are required for energy transmission.

Schillings et al. (2012) on the other hand, considered ship operations, gas and oil drilling, marine sand mining, existing offshore wind power facilities, natural conservation areas, submarine communication cables and pipelines, fishing grounds, military operation areas and wildlife protection areas as the criteria. The study of practical offshore wind energy resource basically considers water depth, conflicting use and environmental sitting constraints without specifying exact site locations.

The applicability of spatial analysis based on multi-criteria decision analysis was also applied by Mahdy \& Bahaj (2018) to provide accurate estimates of offshore wind energy in Egypt. The study also developed suitability maps providing a blueprint for the development of offshore wind farms in potential locations considering shipping routes, ports, military zones, natural park, cable and pipelines, fishing areas and oil and gas extraction areas as the constraints.

\section{Assessment}

\section{Theoretical Potential}

Figure 5 illustrates the annual wind energy that is generated based on ArcMap 10.5 software by implementing the Raster Interpolation with IDW function. To study wind farm energy, an area of $1 \mathrm{~km} \times 1 \mathrm{~km}$, depth of sea water around $10 \mathrm{~m}$ and a distance of $10 \mathrm{~km}$ from the shoreline will be used in the energy calculation. The annual wind energy is calculated solely based on wind speed from satellite altimetry without taking into account any parameters related to wind turbine. Based on the figure illustrated, the darker blue colour points the areas that have the highest wind energy capacity at Central South China Sea as compared to dark brown color region. By limiting the areas to Exclusive Economic Zone (EEZ) of Malaysia and distance to shore, Terengganu, Sarawak and Sabah were the three areas that has been identified as potential wind energy resource with annual wind energy at the average greater than $300 \mathrm{kWh} / \mathrm{m}^{2} /$ year (marked with red stars in the figure below).

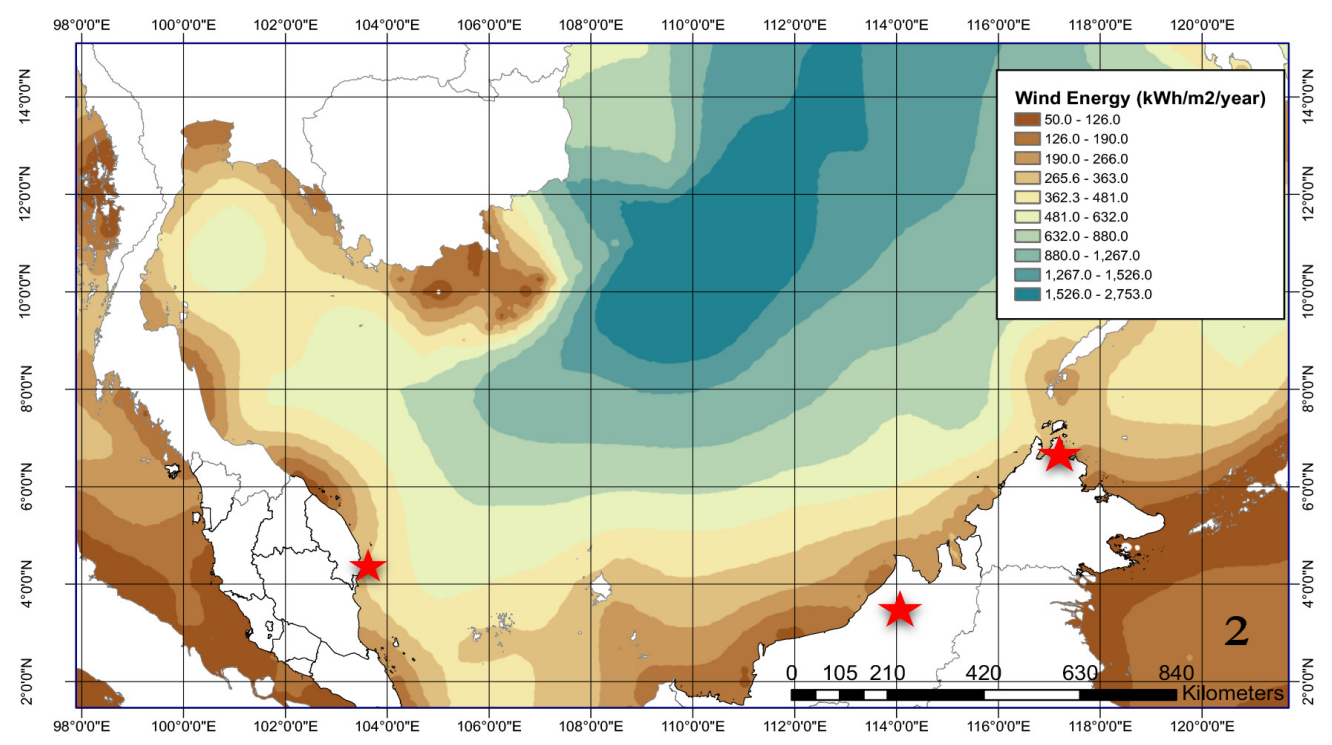

Figure 5: Theoretical offshore wind energy map of Malaysia 2001 to 2010 
Before continuing with the technical resource assessment, the location selected must have sufficient annual mean wind speed of greater than $4 \mathrm{~m} / \mathrm{s}$ and be close enough to the coastline for maintenance operations and connection to the grid. Thus, it is necessary to assess the wind potential at the selected location. Figure 6 illustrates the annual wind speed based on the 10 year multi-mission satellite altimetry for two main monsoon seasons in Malaysia: Southwest and Northeast.

Limiting the area within the range of Exclusive Economic Zone in Malaysia, the wind speed is high during the Northeast monsoon (Figure 6-a) with an average of 6 to $8 \mathrm{~m} / \mathrm{s}$ especially in Terengganu, Sarawak and Sabah while the Southwest monsoon (Figure 6-b) shows mean annual wind speed of less than $6 \mathrm{~m} / \mathrm{s}$. The verdict is at agreement with previous studies conducted on the climatology of wind speed in Malaysia (Lip-Wah et al., 2012; Mekhilef et al., 2012; Uti et al., 2013; Ho, 2016). The annual mean wind speed in the study was obtained by averaging the altimetry wind speed of each month. Terengganu recorded annual mean wind speed of $5.364 \mathrm{~m} / \mathrm{s}$, Sarawak with $5.15 \mathrm{~m} / \mathrm{s}$ while Sabah had an annual mean wind speed of $5.165 \mathrm{~m} / \mathrm{s}$.

\section{Technical Potential}

The technical characteristics and performances of several wind turbines available in the market are gathered and classified in a database. They were selected according to their potential suitability for the establishment of a small scale offshore wind power installation along

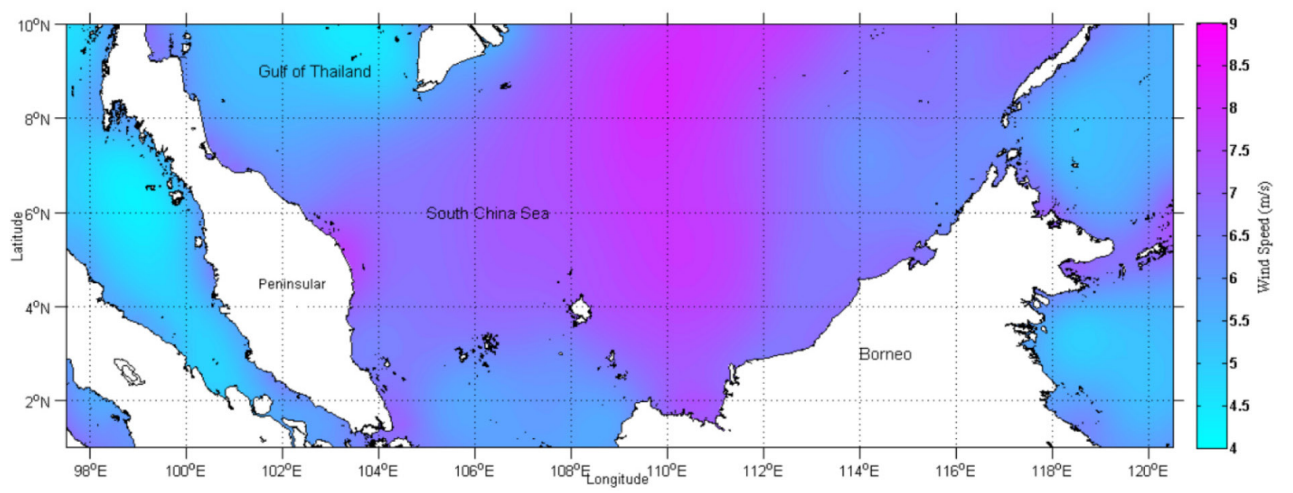

(a) Northeast Monsoon (October-March)

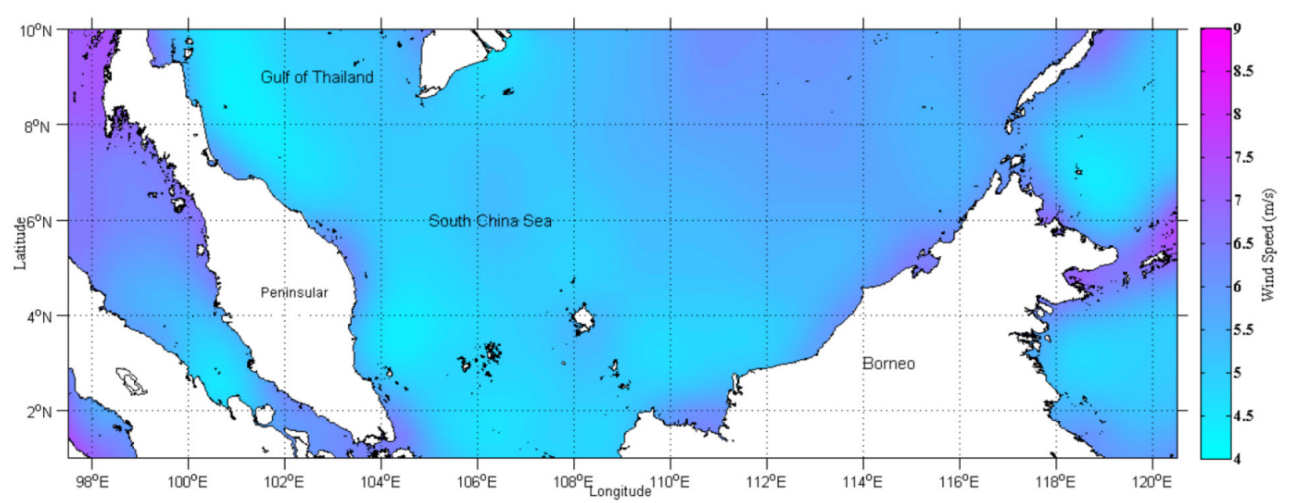

(b) Southwest Monsoon (May-Sept)

Figure 6 : Mean annual wind speed estimates (2001-2010) 
the Malaysian coast. As the annual mean speed of offshore wind in Malaysia does not exceed $6 \mathrm{~m} / \mathrm{s}$, these turbines must show acceptable performances in low wind speed conditions. The selection was mainly based on the power curve and the estimated annual energy production in a $5 \mathrm{~m} / \mathrm{s}$ annual wind speed area were considered. The rated power of the turbines is narrowed down between $60 \mathrm{~kW}$ and $100 \mathrm{~kW}$ due to low wind speed condition in Malaysia.

Table 1 presents the offshore wind turbines considered for this study. The turbines selected for the study are horizontal axis wind turbines as this type of turbine has self-starting ability and works in a wide range of wind speeds with high efficiency. Since all blades of this turbine work simultaneously, it is capable of extracting maximum energy from the wind.

It must be noted that the wind speed will increase with increasing height from the ground level. Modern wind turbines have hub heights greater than $10 \mathrm{~m}$, hence wind speed is extrapolated using Power Law or also known as Hellmann's Exponent, to the hub height for every selected wind turbines. The equation is expressed as follows (Drahansky et al., 2016).

The Hellmann's Exponent value, $\alpha$, used in this study is assumed as 0.1 , which denotes neutral air above the open water.

$$
\frac{v_{2}}{v_{1}}=\left(\frac{z_{2}}{z_{1}}\right)^{\alpha}
$$

$v_{1}=$ velocity at height

$v_{2}=$ velocity at height $v_{1}=$ height 1 (lower height)

$v_{1}=$ height 2 (upper height)

$\alpha=$ wind shear exponent (Hellmannn's exponent)

For the purpose of the technical assessment, the location selected is off Sabah near Kudat. Figure 7 shows the wind speed in Sabah on different height of wind turbine.

The technical power, is obtained by multiplying WPD with the known swept area (A) and power coefficient and it can be expressed as in Equation 4 (Gadad \& Deka, 2016):

$$
P_{i}=(W P D) A C_{P}
$$

Table 2 summarised the offshore wind energy potential in Sabah. The technical output was calculated for one turbine in the location. The technical and theoretical energy in $\mathrm{MWh} /$ year was then calculated and compared to show reduction of energy when dependent on wind turbine. The technical energy is obtained by multiplying technical power with estimated hours of operation for every wind turbine while theoretical energy is determined by multiplying the wind energy density with swept area.

Whereas, Figure 8 presents a comparison between theoretical and technical offshore wind energy output for six selected turbines considered in this study. On average, there is more than $90 \%$ reduction when taking into account the turbine characteristics in the offshore wind energy assessment. Based on the figure and CF, ATB 60.28DD wind turbine can be considered for wind farm development in Malaysia. However,

Table 1: Specification of wind turbine selected for the technical analysis

\begin{tabular}{lccccccc}
\hline Turbine & $\begin{array}{c}\text { Rotor } \\
\text { Diameter } \\
(\mathbf{m})\end{array}$ & $\begin{array}{c}\text { Rated } \\
\text { Power } \\
(\mathbf{k W})\end{array}$ & $\begin{array}{c}\text { Hub } \\
\text { Height }(\mathbf{m})\end{array}$ & $\begin{array}{c}\text { Swept } \\
\text { Area }\left(\mathbf{m}^{\mathbf{2}}\right)\end{array}$ & $\begin{array}{c}\mathbf{( \% )} \\
\text { Estimate } \\
\text { hours } \\
\text { operation }\end{array}$ & $C F$ \\
\hline ErgoWind 60 & 16 & 60 & 24 & 200.0 & 25.0 & 5900 & 0.22 \\
NPS-100C & 24 & 100 & 37 & 467.6 & 23.5 & 7200 & 0.15 \\
Stoma STK60/ & 22 & 60 & 34 & 373.0 & 26.2 & 7200 & 0.17 \\
D21 & & & & & & & \\
Aeolos H-60 & 22 & 60 & 30 & 390.4 & 28.4 & 5900 & 0.17 \\
NPS-60C & 24 & 60 & 37 & 467.6 & 32.1 & 7200 & 0.22 \\
ATB 60.28 & 28 & 60 & 37 & 616.0 & 39.9 & 7200 & 0.31 \\
\hline
\end{tabular}




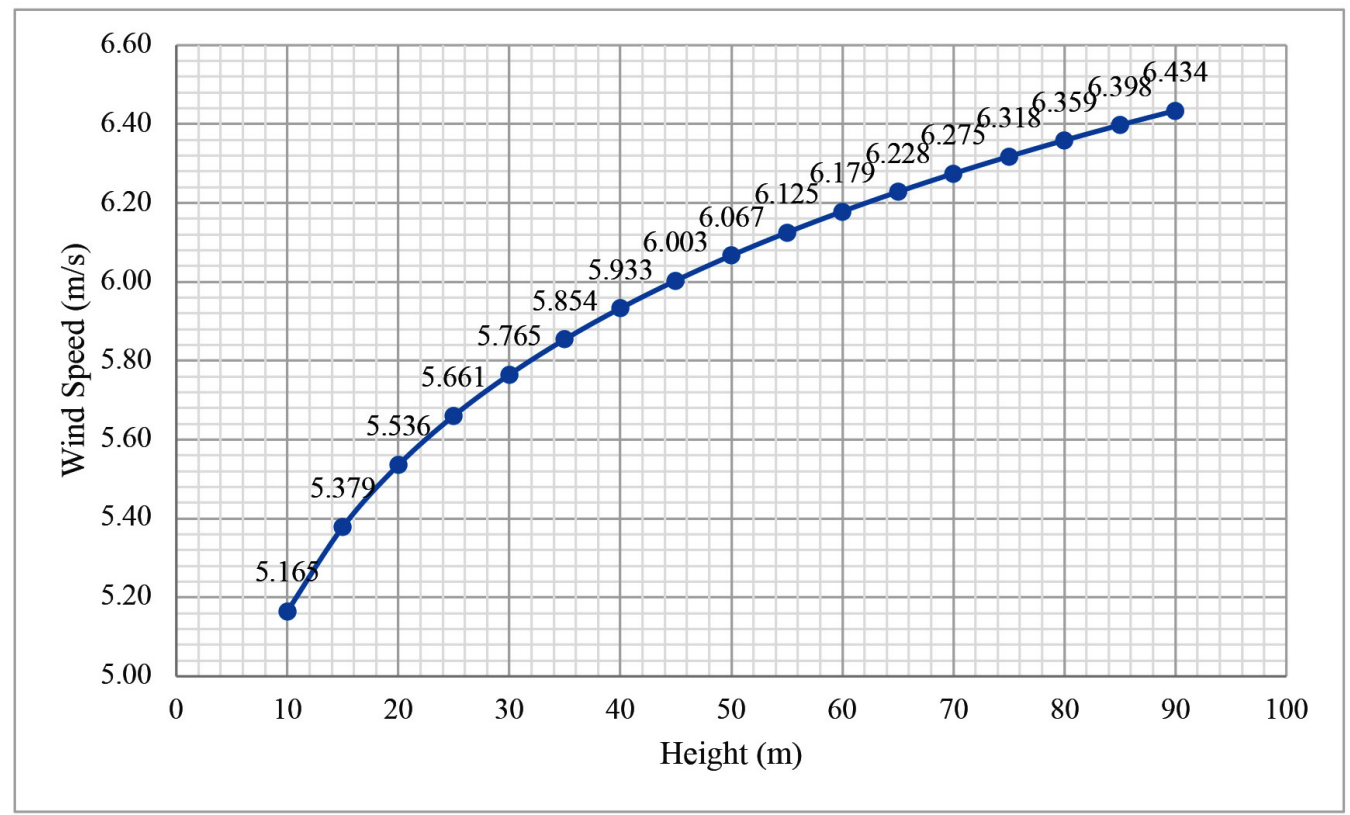

Figure 7: Wind speed of different height of wind turbine selected

Table 2: Offshore wind energy potential in Kudat, Sabah

\begin{tabular}{|c|c|c|c|c|c|c|}
\hline $\begin{array}{l}\text { Turbine } \\
\text { Model }\end{array}$ & $\begin{array}{l}\text { Theoretical } \\
\text { (kW) }\end{array}$ & $\begin{array}{c}\text { WPD } \\
\left(\mathrm{kW} / \mathrm{m}^{2}\right)\end{array}$ & $\begin{array}{c}\text { Wind } \\
\text { Energy } \\
\text { Density } \\
\left(\mathbf{k W h} / \mathbf{m}^{2}\right) \\
\end{array}$ & $\begin{array}{c}\text { Technical } \\
\text { Power }(k W)\end{array}$ & $\begin{array}{c}\text { Technical } \\
\text { Energy } \\
\text { (MWh/year) }\end{array}$ & $\begin{array}{l}\text { Theoretical } \\
\text { Energy } \\
\text { (MWh/year) }\end{array}$ \\
\hline ErgoWind 60 & 21.95 & 109.74 & 961.36 & 1.10 & 1.40 & 192.27 \\
\hline NPS-100C & 58.43 & 124.96 & 1094.67 & 6.42 & 6.70 & 511.87 \\
\hline $\begin{array}{c}\text { Stoma STK60/ } \\
\text { D21 }\end{array}$ & 45.44 & 121.83 & 1067.25 & 4.44 & 5.33 & 398.08 \\
\hline Aeolos H-60 & 45.81 & 117.34 & 1027.92 & 5.08 & 4.99 & 401.30 \\
\hline NPS-60C & 58.43 & 124.96 & 1094.67 & 8.77 & 13.68 & 511.87 \\
\hline ATB 60.28 & 76.98 & 124.96 & 1094.67 & 18.92 & 42.68 & 674.31 \\
\hline
\end{tabular}

it should be kept in mind that the ATB60.28DD has a larger rotor diameter, and thus will take up more space, and may consequently affect the installation cost. For this, the economic analysis is required.

\section{Practical Potential}

The practical mapping plays an important role as it correlates which areas have the potential to harness offshore energy and would thus be appropriate for wind farm development. In this study, a practical map of offshore wind energy resource is developed, taking into consideration several parameters including port, shipping lane, data cable, oil and gas pipeline, exploration contract areas, main fish landing point, oil and gas field. Figure 8 illustrates the physical, socioeconomic and environmental constraints considered for the practical mapping.

As can be seen in the figure below, it is obvious that the three potential locations pointed out from the theoretical potential earlier (see Figure 5) may not be practically suitable for wind farm development due to conflicting 
uses with oil and gas industry and exploration contract area especially in Terengganu and Sabah. The oil and gas pipeline that lies on the seabed may interfere with the installation grid connection and offshore wind turbine support structure, if grounded structure is to be chosen. As for Sarawak, a large number of fish main landing points indicates active commercial fishing activities in this area.

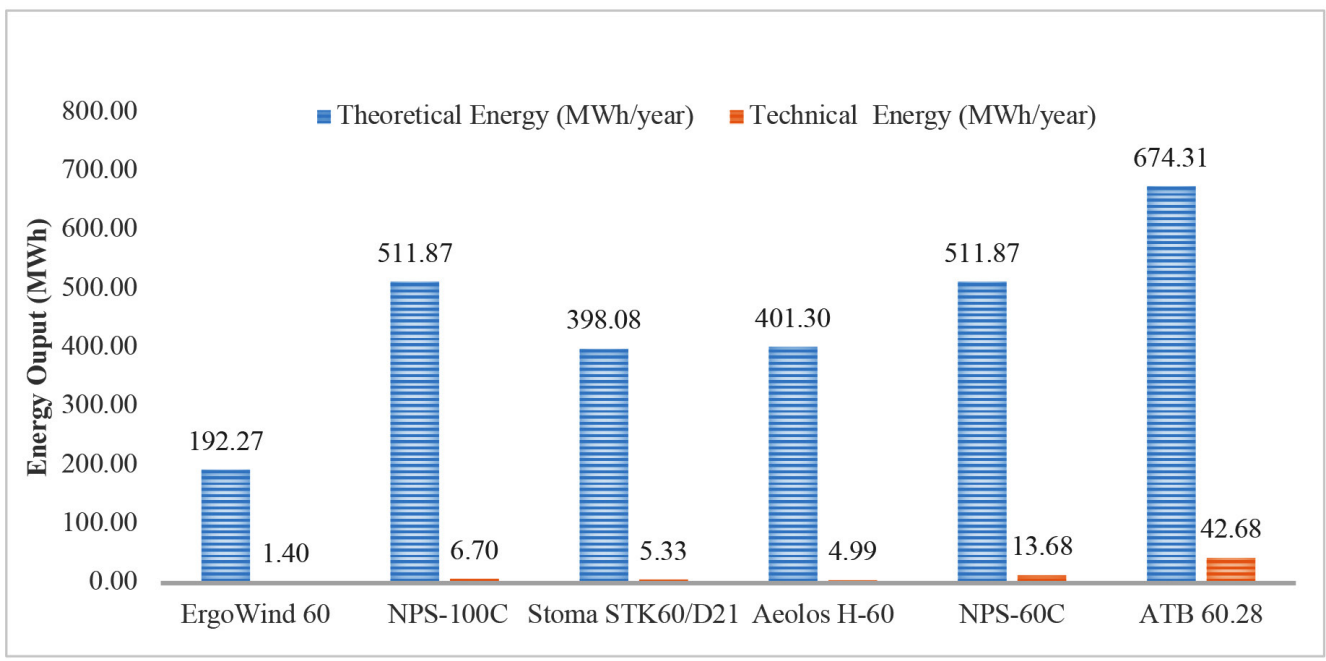

Figure 8: Comparison between theoretical and technical annual wind energy output in Sabah (MWh/year)

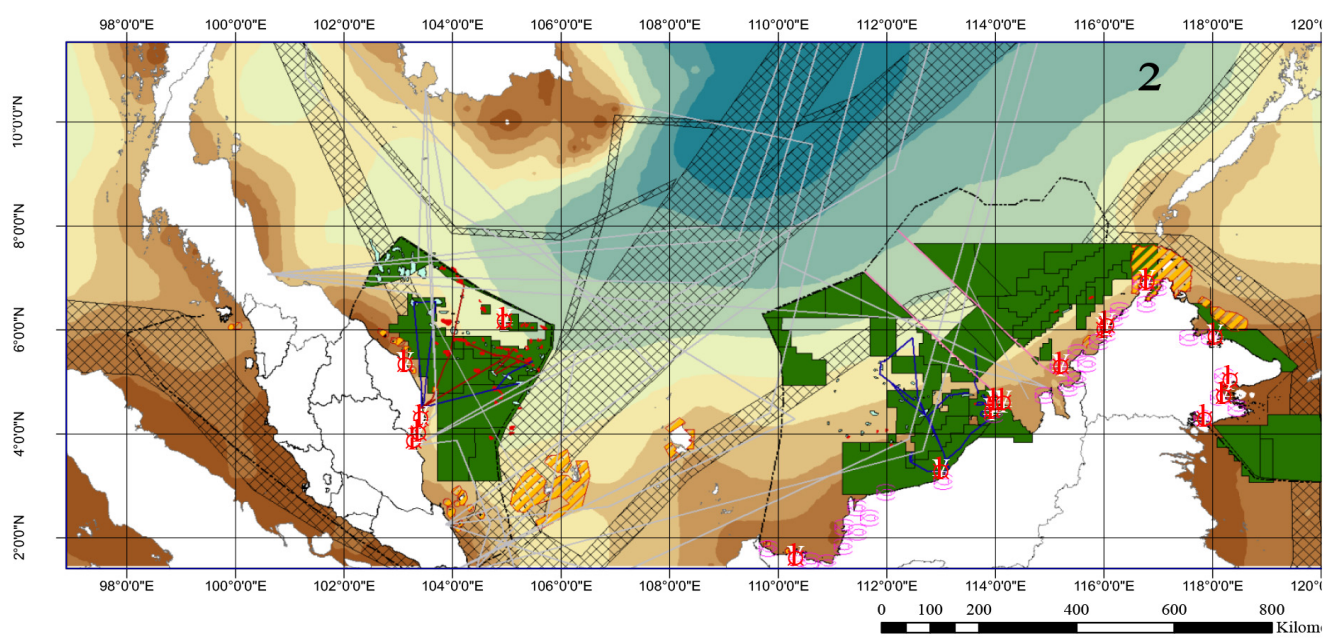

\section{Legend}

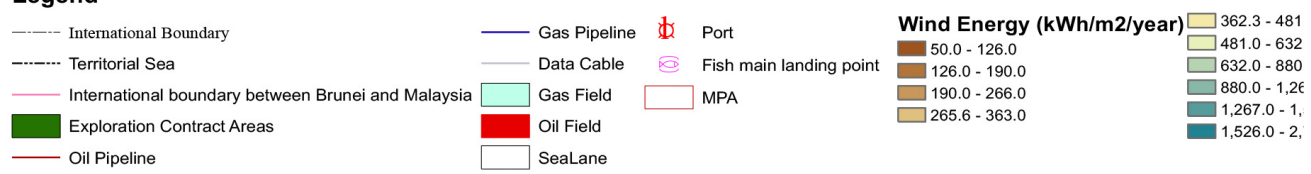

Figure 9: Map of physical, socioeconomic and environmental constraints considered for offshore wind farm development 


\section{Conclusion}

Through the present work, the authors aim to make an assessment based on three different perspectives, theoretical, technical and practical, to give a realistic prospective on offshore wind energy resources within Malaysia. With an annual average wind speed in Malaysia between 4 to $6 \mathrm{~m} / \mathrm{s}$ in Malaysia, three locations within the Exclusive Economic Zone of Malaysia are identified to have potential of offshore wind energy. Theoretically, Terengganu, Sabah and Sarawak have annual offshore wind energy of greater than $500 \mathrm{kWh} / \mathrm{m}^{2}$. However, when taking into account the offshore wind turbine characteristics, more than $90 \%$ reduction of wind energy is seen. It is also observed that among the six wind turbines selected in this study, the ATB 60.28DD could be considered for wind farm development.

A thorough analysis on the technical potential is recommended by applying the array matrix and the number of wind turbine generators. Despite the theoretical and technical potential, it is essential that physical, socioeconomic and environmental constraints are considered in order to analyse the suitability of the potential locations. The practical map revealed to several challenges at the respective areas, that have caused difficulty in the expansion of wind farm that it hinders the effort of the Malaysian government to include offshore wind energy in the renewable energy mix to meet the growing energy demand. The study also highlighted the potential of satellite altimetry as reliable and accurate data source for the assessment to complement the lack of buoy measurement in the vicinity of Malaysia.

\section{Acknowledgments}

The authors would like to express gratitude to the Ministry of Energy, Science, Technology, Environment and Climate Change (MESTECC) for funding the project under the International Collaboration Fund Scheme Project No.: IF1117N0008. The authors wish to thank RADS TuDelft, GNSS and Geodynamics Laboratory,
Universiti Teknologi Malaysia for providing the data for the research.

\section{References}

(IEA), I. E. A. (2006). Technology Roadmap: Wind Energy. In International Energy Agency. https://doi.org/10.1007/1-4020-06 12-8_961

Ahmad Zaman, A. A., Hashim, F. E., \& Yaakob, O. (2019). Satellite-based offshore wind energy resource mapping in Malaysia. Journal of Marine Science and Application, 18(1), 114-121. https://doi.org/10.1007/ s11804-019-00066-w

Albani, A., Ibrahim, M., \& Yong, K. (2014). The feasibility study of offshore wind energy potential in Kijal, Malaysia: The new alternative energy source exploration in Malaysia. Energy Exploration \& Exploitation, 32(2), 329-344.

ATB Riva Calzoni. (n.d.). WTG ATB 60.28 DD. Retrieved June 27, 2019, from https://www. atbrc.com/en/business-sectors/renewables/ wind-power/atb-60.28-dd.html

Chiang, E. P., Zainal, A., Narayana, A., Seetharamu, K. N., \& Pinang, P. (2003). The potential of wave and offshore wind energy in around the coastline of malaysia that face the South China Sea. (September).

Drahansky, M., Paridah, M. ., Moradbak, A., Mohamed, A. ., Owolabi, F. abdulwahab taiwo, Asniza, M., \& Abdul Khalid, S. H. (2016). Methodologies used in the extrapolation of wind speed data at different heights and its impact in the Wind Energy Resource Assessment in a region. Intech, $i$ (tourism), 13. https://doi.org/http://dx.doi. org/10.5772/57353

Energy Commission, M. (2017). Energy Statistics Malaysia 2017. Publication, 1(1), 2017.

Gadad, S., \& Deka, P. C. (2016). Offshore wind power resource assessment using Oceansat-2 scatterometer data at a regional 
scale. Applied Energy, 176, 157-170. https:// doi.org/10.1016/j.apenergy.2016.05.046

Ghazali, F., \& Ansari, A. H. (2018). The Renewable Energy Act 2011: A Study on Renewable Energy Development in Malaysia. International Journal of Law, Government and Communication, 3(7), 143-151. Retrieved from www.ijgc.com

Gulev, S. K., Grigoreiva, V., Andreas, S., \& Woolf, D. (2002). Global-scale wave observations from voluntary observing ships: Assessment of reliability and potentialities for global and off-shore regions studies. Proceedings of the 7th International Workshop on Wave Hindcasting and Forecasting, 11.

Guo, Q., Xu, X., Zhang, K., Li, Z., Huang, W., Mansaray, L. R., ... Huang, J. (2018). Assessing global ocean wind energy resources using multiple satellite data. Remote Sensing, 10(1), 1-13. https://doi. org/10.3390/rs 10010100

Hasager, C. B., Mouche, A., Badger, M., Bingöl, F., Karagali, I., Driesenaar, T., ... Longépé, N. (2015). Offshore wind climatology based on synergetic use of Envisat ASAR, ASCAT and QuikSCAT. Remote Sensing of Environment, 156, 247-263. https://doi. org/10.1016/j.rse.2014.09.030

Ho, L. W. (2016). Wind energy in Malaysia: Past, present and future. Renewable and Sustainable Energy Reviews, 53(January 2016), 279-295. https://doi.org/10.1016/j. rser.2015.08.054

Landau, E. (2019, May 5). Future lies renewable energy. Retrieved June 20, 2019, from New Straits Times website: https://www. nst.com.my/news/nation/2019/05/485777/ future-lies-renewable-energy

Lip-Wah, H., Ibrahim, S., SutarjiKasmin, Omar, C. M. C., \& Abdullah, A. M. (2012). Review of Offshore Wind Energy Assessment and Siting Methodologies for Offshore Wind Energy Planning in Malaysia. American International Journal of Contemporary Research, 2(12), 72-85. Retrieved from
http://www.aijcrnet.com/journals/Vol_2_ No_12_December_2012/8.pdf

Mahdy, M., \& Bahaj, A. B. S. (2018). Multi criteria decision analysis for offshore wind energy potential in Egypt. Renewable Energy, 118, 278-289. https://doi. org/10.1016/j.renene.2017.11.021

Marine Scotland Science. (2018). Scoping "areas of search" study for offshore wind energy in Scottish Waters, 2018. Scotland.

Mekhilef, S., \& Chandrasegaran, D. (2011). Assessment of off-shore wind farms in Malaysia. TENCON 2011-2011 IEEE Region 10 Conference, 1351-1355. Retrieved from http://ieeexplore.ieee.org/ abstract/document/6129028/

Mekhilef, S., Safari, A., \& Chandrasegaran, D. (2012). Feasibility study of off-shore wind farms in Malaysia. Energy Education Science and Technology Part A: Energy Science and Research, 29(1), 519-530.

Musial, W., Heimiller, D., Beiter, P., Scott, G., \& Draxl, C. (2016). 2016 Offshore Wind Energy Resource Assessment for the United States. USA.

Nie, B., \& Li, J. (2018). Technical potential assessment of offshore wind energy over shallow continent shelf along China coast. Renewable Energy, 128(2018), 391-399. https://doi.org/10.1016/j. renene.2018.05.081

Rusu, L. (2019). The wave and wind power potential in the western Black Sea. Renewable Energy, 139, 1146-1158. https:// doi.org/10.1016/j.renene.2019.03.017

Schillings, C., Wanderer, T., Cameron, L., van der Wal, J. T., Jacquemin, J., \& Veum, K. (2012). A decision support system for assessing offshore wind energy potential in the North Sea. Energy Policy, 49, 541-551. https://doi.org/10.1016/j.enpol.2012.06.056

Syakirah, W., Abdullah, W., Osman, M., Zainal, M., \& Ab, A. (2019). The Potential and Status of Renewable Energy. Energies, 12, 2437. https://doi.org/10.3390/en12122437 
Uti, M. N., Din, A. H. M., \& Omar, A. H. Witter, D. L., \& Chelton, D. B. (1991). A Geosat (2013). Reliability of wind speed data from satellite altimeter to support wind turbine energy. International Archives of the Photogrammetry, Remote Sensing and Spatial Information Sciences - ISPRS Archives, 42(4W5), 215-224. https:// doi.org/10.5194/isprs-archives-XLII4-W5-215-2017

Wan, Y., Zhang, J., Meng, J., \& Wang, J. (2015). A wave energy resource assessment in the China's seas based on multi-satellite merged radar altimeter data. Acta Oceanologica Sinica, 34(3), 115-124. https://doi. org/10.1007/s13131-015-0627-6 altimeter wind speed algorithm and a method for altimeter wind speed algorithm development. Journal of Geophysical Research:, 96(C5), 8853-8860.

Yaakob, O., Hashim, F., Omar, K., Din,A., \& Koh, K. (2016). Satellite-based wave data and wave energy resource assessment for South China Sea. Renewable Energy. Retrieved from http://www.sciencedirect.com/ science/article/pii/S0960148115304572

Ye, X., Lin, M., \& Xu, Y. (2015). Validation of Chinese HY-2 satellite radar altimeter significant wave height. Acta Oceanologica Sinica, 34(5), 60-67. https://doi. org/10.1007/s13131-015-0667-y 